\title{
ALS in Danish Registries
}

\section{Heritability and links to psychiatric and cardiovascular disorders}

Betina B. Trabjerg, MSc, Fleur C. Garton, PhD, Wouter van Rheenen, MD, PhD, Fang Fang, MD, PhD, Robert D. Henderson, MBBS, PhD, Preben Bo Mortensen, DrMedSc, Esben Agerbo, DrMedSc, and Naomi R. Wray, PhD

Neurol Genet 2020;6:e398. doi:10.1212/NXG.0000000000000398

\section{Abstract}

\section{Objective}

To investigate the genetic contribution to amyotrophic lateral sclerosis (ALS) and the phenotypic and genetic associations between ALS and psychiatric and cardiovascular disorders (CVD) we used the national registry data from Denmark linked to first-degree relatives to estimate heritability and cross-trait parameters.

\section{Methods}

ALS cases and 100 sex and birth-matched controls per case from the Danish Civil Registration System were linked to their records in the Danish National Patient Registry. Cases and controls were compared for (1) risk of ALS in first-degree relatives, used to estimate heritability, (2) comorbidity with psychiatric disorders and CVD, and (3) risk of psychiatric disorders and CVD in first-degree relatives.

\section{Results}

5,808 ALS cases and 580,800 controls were identified. Fifteen percent of cases and controls could be linked to both parents and full siblings, whereas $70 \%$ could be linked to children. (1) We estimated the heritability of ALS to be 0.43 (95\% CI, 0.34-0.53). (2) We found increased rates of diagnosis of mental disorders (risk ratio $=1.18 ; 95 \% \mathrm{CI}, 1.09-1.29$ ) and CVD in those later diagnosed with ALS. (3) In first-degree relatives of those with ALS, we found increased rate of schizophrenia (1.17; 95\% CI, 0.96-1.42), but no evidence for increased risk CVD.

\section{Conclusions}

Heritability of ALS is lower than commonly reported. There is likely a genetic relationship between ALS and schizophrenia, and a nongenetic relationship between ALS and CVD.

\author{
Correspondence \\ Dr. Wray \\ Naomi.Wray@uq.edu.au.
}




\section{Glossary}

ALS = amyotrophic lateral sclerosis; CRS = Civil Registration System; CVD = cardiovascular disease /cardiovascular disorder; GWAS = genome-wide association study; ICD = International Classifications of Disease; $\mathbf{M I}=$ myocardial infarction; $\mathbf{R R}=$ risk ratio.

Multiple genes ${ }^{1}$ (e.g., SOD1 and C9orf72) can harbor causal mutations of amyotrophic lateral sclerosis (ALS) found in $5 \%-10 \%$ of those diagnosed, ${ }^{2}$ mostly those with many affected family members. Genetic factors likely contribute to ALS when these mutations are absent. Heritability of liability quantifies the relative genetic contribution to the disease, assuming a polygenic architecture. Estimates of heritability ${ }^{3-7}$ (table 1) are difficult to obtain for late-onset disorders because the essential information required is the increased risk of disease in relatives of those affected. This is particularly difficult for a disorder such as ALS where lifetime risk is $\sim 0.25 \% .{ }^{8,9}$

More recently, genome-wide association study (GWAS) data have enabled estimation of the proportion of variation in liability associated with genome-wide single nucleotide polymorphisms $\left(\right.$ SNP-based heritability $\left.{ }^{10}\right)$. For ALS, SNP-based heritability has been estimated to be $8.2 \%$ (95\% CI, 7.2-9.2), ${ }^{11}$ which provides a lower bound for heritability (because the estimate only captures variation associated with the GWAS common SNPs) and demonstrates evidence in support of a polygenic architecture. SNPbased heritability methods have bivariate extensions ${ }^{12,13}$ that allow estimation of genetic correlations using GWAS summary statistics from independently collected disease cohorts. Application of these methods to ALS gave a significant estimate for a genetic correlation of ALS with schizophrenia $(0.14,95 \% \mathrm{CI}, 0.07-0.21) .{ }^{14} \mathrm{By}$ contrast, the estimated genetic correlation with cardiovascular disease (CVD) was not different from zero, ${ }^{15}$ despite increased rates of CVD in those with ALS. ${ }^{16}$ Here, we apply genetic epidemiology approaches to population records of ALS from Denmark with the objective to provide independent evidence for genetic associations between ALS and other disorders.

\section{Methods}

\section{Study population}

The Danish Civil Registration System (CRS) was established in 1968, registering all people alive and living in Denmark ${ }^{17}$ with a unique personal identifier (CRS number). All other national registries can be linked using the CRS number. Our study population included all persons alive in Denmark from January 1, 1968, or born between 1969 and January 1, 2017. The study was approved by the Danish Health Data Authority, the Danish Data Protection Agency, and Statistics Denmark and did not require ethical approval because its use serves a scientific cause and no reference is made to a single person.

\section{ALS cases}

ALS cases were identified using the Danish National Patient Registry $^{18}$ (established January 1, 1977, accessing records until
January 1, 2017). The patient registry records any individual with a hospital admission and covers information on all Danish somatic inpatient hospital contacts; outpatient contacts were included from January 1, 1994. We considered both main and auxiliary diagnoses for inpatient and outpatient contacts. Inclusion was based on persons who were living in Denmark at the time, were older than 16 years at the time of their first diagnosis, and had International Classifications of Disease (ICD) 8:348.0 or icd-10:G12.2 codes included in their records. These definitions have been used in previous studies of ALS using the Danish registry, ${ }^{19-22}$ and a very good agreement in diagnosis has been reported with death certificate data. ${ }^{19} \mathrm{~A}$ published validation study used these ICD codes for cases identified from the registry data and confirmed the ALS diagnosis in 160 of 173 ALS cases (92.5\%) and found no difference in the predictive validity between ICD-8 and ICD-10 codes. $^{22}$

\section{Controls}

For each case that was identified, 100 controls were extracted and matched for sex and date of birth (alive and living in Denmark at the time case diagnosis was first recorded). Particularly, for older cases, it was not possible to find 100 controls matched for an exact date of birth. Where necessary, the window was increased by \pm 1 day until the quota of controls was reached. The controls were sampled without replacement, and the cases could not be selected as controls.

\section{Identification of family members}

After the selection of ALS cases and controls, parents, siblings, or children were identified when possible. For people registered as children, a link to the CRS number of their legal parents is created. Since the registry was established in 1968, only those born after $\sim 1950$ (aged 18 years or younger at the time when the registry was established) are expected to have parental CRS records. Full siblings could only be identified for those who had both parents linked to their records. Similarly, in identifying children of cases, only children born after 1950 and before 2017 would be identified. We note that the CRS system identifies legal parents; although these are expected to mostly reflect biological relationships, this will not always be true. We count parents, siblings, and children as first-degree relatives.

\section{Psychiatric and CVD diagnoses}

Information on individuals diagnosed with schizophrenia and other mental disorders was obtained from the Danish Psychiatric Central Research Register. ${ }^{23}$ From 1969, this Registry contained data on all admissions to Danish psychiatric inpatient facilities (secondary care treatment). From 1995, information on all contacts to outpatient psychiatric departments and visits 
Table 1 A summary of the studies estimating risk in relatives and/or estimating heritability

\begin{tabular}{|c|c|c|c|c|c|}
\hline Reference & Description & Exclude $^{a}$ & Lifetime risk & $\begin{array}{l}\text { RR in first-degree } \\
(95 \% \mathrm{CI})\end{array}$ & $\begin{array}{l}\text { Reported estimate of } \\
\text { heritability }(95 \% \mathrm{CI})\end{array}$ \\
\hline Graham et al. ${ }^{35}$ & $\begin{array}{l}77(26 \mathrm{MZ}, 51 \mathrm{DZ}) \text { twin pairs with at least } \\
\text { one affected twin. } 4 \mathrm{MZ} \text { concordant ( } 2 \text { from } \\
\text { families with many affected individuals) }\end{array}$ & No & & & $0.38-0.85$ \\
\hline Fang et al. ${ }^{4}$ & $\begin{array}{l}\text { 6,671 ALS cases identified in Swedish } \\
\text { national records. Prospective study following } \\
1,906 \text { siblings, } 13,947 \text { children, and 5,405 spouses }\end{array}$ & No & & $9.7(7.2-12.8)$ & \\
\hline Al-Chalabi et al. ${ }^{3}$ & $\begin{array}{l}171(49 \mathrm{MZ}, 122 \mathrm{DZ}) \text { twin pairs with at least } \\
\text { one affected twin. } 5 \text { concordant } \mathrm{MZ} \text { twin pairs. } \\
\text { Includes Graham et al. }{ }^{35} \text { sample. }\end{array}$ & No & $\begin{array}{l}0.25 \% \\
0.19 \% \text { to age } 70\end{array}$ & & $0.61(0.38-0.78)$ \\
\hline Wingo et al. ${ }^{5}$ & $\begin{array}{l}\text { 1,088 clinic probands, } 8 \text { had affected fathers } \\
\text { and } 16 \text { had affected mothers. }\end{array}$ & No & $\begin{array}{l}\text { M: } 0.20 \% \\
\text { F: } 0.15 \%\end{array}$ & $\begin{array}{l}\text { Range: } 2.2-6.9 \\
\text { Mid: } 4.6\end{array}$ & $0.36-0.48^{b}$ \\
\hline Hanby et al. ${ }^{36}$ & $\begin{array}{l}\text { 1,502 clinic probands, } 8 / 1,622 \text { full siblings, } \\
18 / 1,545 \text { children from the same clinic }\end{array}$ & Yes & $0.3 \%^{c}$ & 8 & \\
\hline Ryan et al. $^{7}$ & $\begin{array}{l}\text { 1,117 Irish registry probands. } 18 \text { parent/child } \\
\text { affected pairs (after excluding C9orf } 72 \text { ). } \\
\text { All parents recorded }\end{array}$ & Yes & $\begin{array}{l}\text { M: } 0.29 \% \\
\text { F: } 0.23 \%\end{array}$ & 5.5 & $0.37(0.20-0.54)$ \\
\hline This paper & $\begin{array}{l}5,808 \text { Danish registry probands, 580,800 } \\
\text { sex-age matched controls }\end{array}$ & No & $0.25 \%^{\mathrm{c}}$ & $5.8(4.17-8.00)$ & $0.43(0.34-0.53)$ \\
\hline
\end{tabular}

Abbreviations: $M Z$ = monozygotic twins; $\mathrm{DZ}$ = dizygotic twins; $\mathrm{RR}=$ relative risk.

a Here, we note if cases carrying known mutations or from families with many affected individuals were excluded, recognizing that any exclusion is likely to be incomplete.

b The range reflects estimates based on alternative scenarios, particularly changing lifetime risk.

cAssumed, not estimated in data.

to psychiatric emergency care units was included. For all cases and controls and their identified first-degree relatives, endorsements of records for psychiatric diagnoses were obtained $^{24}$ (table e-1, links.lww.com/NXG/A224). The same hospital registry that was used to identify ALS cases, the Danish National Patient Registry, was also used to identify all persons with any diagnosis of heart disease. We defined heart disease under both a broad definition of CVD and a narrower definition of myocardial infarction $(\mathrm{MI})^{20}$ (table e-1). The psychiatric or CVD diagnoses in both cases and their matched controls were restricted to those recorded before the first record of ALS for the case. We estimated risk of psychiatric disorders and CVD in ALS cases and controls and calculated risk ratios (RRs).

\section{Quantitative genetic modeling}

We estimated the increased risk of ALS in relatives of the cases compared with the controls for different types of relatives.

When families have 3 or more affected first-degree relatives, it is very likely that they have a mendelian type of ALS, given a lifetime risk for ALS of $\sim 0.25 \%$. However, co-occurrence of ALS in a pair of relatives could be explained by shared genetic factors under a more polygenic model of disease (or even by shared environment). Many other diseases have mendelian and polygenic types (such as breast cancer, Parkinson disease, and Alzheimer disease). Under a polygenic genetic architecture, even when the total genetic contribution to disease etiology is high, most people affected present without a family history. ${ }^{25}$ Here, we assume that the observed increased risk in first-degree relatives is attributed to a polygenic contribution (the same assumptions as made in the studies listed in table 1) and estimate the heritability of ALS under the liability threshold model, ${ }^{26-28}$ assuming a lifetime risk of $0.25 \%$. Recognizing that families harboring the known causal mutations cannot be identified from the registry data, we conducted sensitivity analyses and re-estimated heritability removing $20 \%$ of counts of ALS concordant relative pairs. Last, we estimated the risk of psychiatric disorders or CVD in relatives of ALS cases and controls. We used bivariate liability threshold methods to link risk in relatives to genetic correlation, ${ }^{27,28}$ assuming estimates of heritability for these traits made from Danish national registry data. ${ }^{28}$

\section{Data availability}

Access to individual-level Denmark data is governed by Danish authorities. These include the Danish Data Protection Agency, the Danish Health Data Authority, and Statistics Denmark. Each scientific project must be approved before initiation, and approval is granted to a specific Danish research institution. International researchers may gain data access through collaboration with a Danish research institution.

\section{Results}

\section{Cases and controls}

We identified 5,808 ALS cases (3,227 men and 2,581 women), of which $62 \%$ had an ICD-10:G122 diagnosis, 27\% ICD-8: 34809, and 10\% ICD-10:G122G. These statistics are in good agreement with the studies which previously accessed the ALS 
records from Danish registers. ${ }^{19-22}$ For more than $94 \%$ of cases, all their matched controls were born within 2 days (table e-2, links.lww.com/NXG/A224). The birth years of the cases ranged from 1886 to 2000 , but given that ALS is typically a disease of late-onset, 94\% of cases were born before 1960 (table e-3). We found that annual incidence was higher in later years (figure e-1), consistent with the previously reported increase in age-adjusted incidence of $1.6 \%$ annually after $1982 .{ }^{21}$ Because some people with ALS have no need for an inpatient hospitalization, the addition of outpatient records in 1994 may partially account for incidence increase. The median age at diagnosis for the ALS cohort (minimum age of diagnosis of 16 years) was 67.1 years (interquartile range 58.4-74.2 years) (figure e-2).

\section{Relatives}

As a reflection of the timing of the registry establishment, the percentage of those with a link to a mother increased rapidly from $9.7 \%$ for those born in 1950 to $98.6 \%$ and $99.8 \%$ for those born in 1960 and 1970, respectively, retaining that level for all subsequent birth years. Similar findings were obtained regarding a link to a father. Given the age distribution for ALS diagnosis, only $16 \%$ of cases/controls could be linked to their mother, $15 \%$ could be linked to their father, and $15 \%$ could be linked to both parents, with no difference between the cases and controls ( $\chi^{2}$ test, $\left.p=0.12\right)$ (table e-4, links.lww.com/NXG/A224). Only those linked to their parents could have their siblings identified (table e-5). By contrast, children could be identified for $70 \%$ of people (table e-6). Overall, 74\% of people had at least one first-degree relative identified in the registry data (table e-7). In these data, no ALS case or control had more than one affected sibling and the number of individuals with more than one affected child was less than 4 (concern about potential reidentification means that the exact number is nonreportable). The rate of ALS was $0.15 \%$ in mothers of controls and $0.20 \%$ in fathers of controls (among only the 15\% controls with their parents identified) (table 2). Because ALS is a late-onset disorder, the parents of controls matched to the cases must be close to a full lifetime in age; hence, these rates provide a lower bound on lifetime risk.

\section{Estimate of heritability}

The RR of ALS in first-degree relatives of ALS cases compared with those of the controls ranged from 4.2 in fathers to 12.8 in

Table 2 Counts of ALS in each relative type of ALS cases and controls and RRs for ALS cases compared with ALS controls

\begin{tabular}{|c|c|c|c|c|c|c|c|}
\hline & \multicolumn{3}{|c|}{ No record of ALS in Relative } & \multicolumn{3}{|c|}{ Relative is recorded as having ALS } & \multirow[b]{2}{*}{$\mathbf{R R}^{\mathbf{a}}$} \\
\hline & Control & Case & Total & Control & Case & Total & \\
\hline \multicolumn{8}{|l|}{ Mother } \\
\hline Count & 95,224 & 895 & 96,119 & 144 & 8 & 152 & 5.87 \\
\hline$\%^{\mathbf{b}}$ & 99.8 & 99.1 & & 0.2 & 0.9 & & $2.89-11.9$ \\
\hline \multicolumn{8}{|l|}{ Father } \\
\hline Count & 90,216 & 847 & 91,063 & 177 & 7 & 184 & 4.19 \\
\hline$\%^{\mathrm{b}}$ & 99.8 & 99.2 & & 0.2 & 0.8 & & $1.97-8.88$ \\
\hline \multicolumn{8}{|c|}{ Full sibling } \\
\hline Count & 61,962 & 587 & 62,549 & 65 & 8 & 73 & 12.8 \\
\hline$\%^{\mathbf{b}}$ & 99.9 & 98.7 & & 0.1 & 1.3 & & $6.2-26.6$ \\
\hline \multicolumn{8}{|l|}{ Child } \\
\hline Count & 414,290 & 4,050 & 418,340 & 277 & 15 & 292 & 5.52 \\
\hline$\%^{b}$ & 99.93 & 99.63 & & 0.07 & 0.37 & & $3.29-9.28$ \\
\hline \multicolumn{8}{|c|}{ First-degree } \\
\hline Count & 433,005 & 4,270 & 437,275 & 662 & 38 & 700 & 5.78 \\
\hline$\%^{b}$ & 99.8 & 99.1 & & 0.2 & 0.9 & & $4.17-8.00$ \\
\hline \multicolumn{8}{|c|}{ Sensitivity first-degree $^{c}$} \\
\hline Count & 433,005 & 4,270 & 437,275 & 662 & 30 & 700 & 4.57 \\
\hline$\%^{\mathbf{b}}$ & 99.8 & 99.1 & & 0.2 & 0.7 & & $3.17-6.58$ \\
\hline $\begin{array}{l}\text { Abbreviat } \\
\text { Bold type } \\
\text { a Calculat } \\
{ }^{b} \text { Percent } \\
\text { ' Sensitivit }\end{array}$ & $\begin{array}{l}\text { lateral scl } \\
\text { are signific } \\
\text { orary fmsb } \\
\text { count. } \\
\text { of case-co }\end{array}$ & $\begin{array}{l}R R=\text { risk } \\
\text { ifferent } \\
\text { th pairs }\end{array}$ & le mono & hence & count c & & \\
\hline
\end{tabular}


Table 3 Estimates of heritability of ALS based on relative risk of ALS for different type of relatives

\begin{tabular}{|c|c|c|c|c|c|c|}
\hline & Mothers & Fathers & Siblings & Children & First-degree & Sensitivity \\
\hline Risk for relatives of controls (\%) & 0.15 & 0.20 & 0.10 & 0.07 & 0.15 & 0.15 \\
\hline Risk for relatives of cases (\%) & 0.89 & 0.82 & 1.34 & 0.37 & 0.88 & 0.70 \\
\hline Increased risk of ALS in relatives of those with ALS & 5.87 & 4.19 & 12.83 & 5.52 & 5.78 & 4.57 \\
\hline s.e. of estimate & 0.36 & 0.39 & 0.38 & 0.27 & 0.17 & 0.19 \\
\hline $95 \% \mathrm{Cl}$ & $2.89-11.9$ & $1.97-8.88$ & $6.18-26.6$ & $3.29-9.28$ & $4.17-8.00$ & $3.17-6.58$ \\
\hline Estimate of heritability, assuming lifetime risk $0.25 \%$ & 0.44 & 0.34 & 0.68 & 0.42 & 0.43 & 0.36 \\
\hline s.e. of estimate & 0.11 & 0.10 & 0.13 & 0.08 & 0.05 & 0.05 \\
\hline $95 \% \mathrm{Cl}$ & $0.24-0.66$ & $0.15-0.56$ & $0.45-0.95$ & $0.28-0.58$ & $0.34-0.53$ & $0.27-0.47$ \\
\hline
\end{tabular}

Abbreviations: $\mathrm{ALS}=$ amyotrophic lateral sclerosis; $\mathrm{RR}=$ risk ratio; s.e. $=$ standard error.

Heritability following liability threshold methodology, ${ }^{26-28}$ assuming lifetime risk of $\mathrm{K}=0.0025 .95 \% \mathrm{Cl}$ are calculated using the $95 \% \mathrm{Cl}$ of the $\mathrm{RR}$, as the only estimated value in the equation.

a Sensitivity analysis using the risk to relatives from the sensitivity row in table 2.

siblings (table 3). Despite this range, the 95\% CI was overlapping. Across all first-degree relatives, there is a 5.78 -fold (95\% CI, 4.17-8.00) increase in the risk of ALS in relatives of the cases compared with in relatives of the controls. This generates an estimate of heritability of 0.43 (95\% CI, $0.34-0.53$ ), given a lifetime risk ${ }^{8,9}$ of $0.25 \%$ (table 3). Sensitivity analyses assumed lifetime risks of ALS in Denmark of $0.2 \%$ or $0.3 \%$, which gave heritability estimates of 0.41 ( $95 \% \mathrm{CI}$, $0.32-0.50$ ) and 0.45 (95\% CI, 0.35-0.55), respectively, (tables e-8 and e-9, links.lww.com/NXG/A224). The methodology to estimate heritability assumes that the disease is polygenic, and hence, the estimate provided here is an upper limit of heritability on the liability scale because some of the first-degree relatives concordant for ALS may reflect families harboring mendelian mutations; as such, it is not possible to identify these families from the registry data. In a sensitivity analysis, with an exclusion of $20 \%$ of concordant pairs, the estimate of the relative risk reduced to 4.57 (95\% CI, 3.17-6.58) and that of heritability reduced to 0.36 (95\% CI, 0.27-0.47) (table 3). We note that no family included more than 2 affected individuals, and we were unable to find reports of rates of ALS mendelian mutations in Denmark. Given the intercountry variability, it is possible that the rates of ALS dominant mutations are not high. For example, in an international study, ${ }^{29}$ the most common form of mendelian ALS, associated with the hexanucleotide repeat in the gene C9orf 72 , was less frequent in the Netherlands and Sweden (albeit the latter from a small sample) than in other countries; Denmark did not contribute to the study.

\section{Cross-trait analyses within individual and for relatives}

We estimated the risk of psychiatric disorders and CVD before ALS diagnosis date in those with ALS and their matched controls (table 4). We found an increased risk of CVD (RR) of (1.21; $95 \%$ CI, 1.15-1.27, $\left.p=6 \times 10^{-15}\right)$ in those with ALS compared with those without (as previously reported ${ }^{16}$ ), but the increased risk was not significant for MI $(\mathrm{RR}=1.08$; 95\% CI, 0.96-1.22, $p=$
$0.19)$. We also found an increased risk of all psychiatric disorders $\left(\mathrm{RR}=1.18\right.$; 95\% CI, 1.09-1.29, $\left.p=1.3 \times 10^{-4}\right)$ likely reflecting an increased risk in affective disorders excluding bipolar disorder $(\mathrm{RR}=1.20 ; 95 \% \mathrm{CI}, 1.03-1.40, p=0.019)$. These affective disorders affect $2.4 \%$ of the controls (i.e., reflecting mostly hospitalized unipolar disorder), noting that the Danish Psychiatric Central Research Register does not include depression treated in primary care. There is no increased risk of severe psychiatric disorders such as schizophrenia, bipolar disorder, and anorexia.

We estimated the risk of psychiatric and CVD disorders in firstdegree relatives of those with and without ALS. When considering all first-degree relatives together, none of the risks to relatives were significant (table 5). The highest increased risk was 1.17 (95\% CI, 0.97-1.42; $p=0.10$ ) for schizophrenia (table 5 ). Despite being nonsignificant, the increased risk was in the direction expected from the genetic correlation estimates from GWAS summary data. ${ }^{14}$ Using lifetime risk and heritability estimates ${ }^{28} 0.0112$ and 0.67 , respectively for schizophrenia, and of 0.0025 and 0.43 , respectively for ALS, and assuming a genetic correlation of $0.14,{ }^{14}$ we estimate the expected RR to be 1.32 , which is within the $95 \% \mathrm{CI}$ of our estimate. When considering different first-degree relatives, we found an increased risk of schizophrenia in mothers of ALS cases $(\mathrm{RR}=2.21 ; 95 \%$ CI, 1.05-4.65, $p=0.033$ ) and increased risk of all mental disorders in fathers of ALS case ( $\mathrm{RR}=1.29 ; 95 \% \mathrm{CI}, 1.08-1.53$, $p=0.0053)$ (table e-8, links.lww.com/NXG/A224).

\section{Discussion}

Recorded in over 48 years of Danish national patient and outpatient registries were 5,808 ALS cases, who were matched with 580,800 controls. The increased risk of ALS in firstdegree relatives of those with ALS compared with first-degree relatives of controls was 5.78 (95\% CI, 4.17-8.00). The resulting estimate of heritability was 0.43 ( $95 \% \mathrm{CI}, 0.34-0.53$ ). This has a lower mean and smaller bounds than the published 
Table 4 Disease/disorder counts in 5,808 ALS cases and 580,800 matched controls before ALS diagnosis in the case and RRs for ALS cases compared with ALS controls

\begin{tabular}{|c|c|c|c|c|c|c|c|}
\hline & \multicolumn{3}{|c|}{ Given disorder not recorded for individual } & \multicolumn{3}{|c|}{ Given disorder is recorded for individual } & \multirow[b]{2}{*}{ RR $95 \% \mathrm{Cl}$} \\
\hline & Control & Case & Total & Control & Case & Total & \\
\hline \multicolumn{8}{|c|}{ All mental disorders } \\
\hline Count & 539,719 & 5,322 & 545,041 & 41,081 & 486 & 41,567 & 1.18 \\
\hline$\%^{a}$ & 92.9 & 91.6 & & 7.1 & 8.4 & & $1.09-1.29$ \\
\hline \multicolumn{8}{|c|}{ Schizophrenia } \\
\hline Count & 578,125 & 5,785 & 583,910 & 2,675 & 23 & 2,698 & 0.86 \\
\hline$\%^{a}$ & 99.5 & 99.6 & & 0.5 & 0.4 & & $0.57-1.30$ \\
\hline \multicolumn{8}{|c|}{ Other psychotic disorders } \\
\hline Count & 576,735 & 5,766 & 582,501 & 4,065 & 42 & 4,107 & 1.03 \\
\hline$\%^{a}$ & 99.3 & 99.3 & & 0.7 & 0.7 & & $0.76-1.40$ \\
\hline \multicolumn{8}{|c|}{ Bipolar disorder } \\
\hline Count & 578,159 & 5,772 & 583,931 & 2,641 & 36 & 2,677 & 1.36 \\
\hline$\%^{a}$ & 99.6 & 99.4 & & 0.5 & 0.6 & & $0.98-1.89$ \\
\hline \multicolumn{8}{|c|}{ Other affective disorders } \\
\hline Count & 567,121 & 5,644 & 572,765 & 13,679 & 164 & 13,843 & 1.20 \\
\hline$\%^{a}$ & 97.6 & 97.2 & & 2.4 & 2.8 & & $1.03-1.40$ \\
\hline \multicolumn{8}{|l|}{ Anorexia } \\
\hline Count & 580,719 & 5,808 & 586,527 & 81 & 0 & 81 & 0.62 \\
\hline$\%^{a}$ & 99.99 & 100.00 & & 0.01 & 0.00 & & $0.04-10.0$ \\
\hline \multicolumn{8}{|c|}{ Heart disease } \\
\hline Count & 467,227 & 4,435 & 471662 & 113,573 & 1,373 & 114,946 & 1.21 \\
\hline$\%^{a}$ & 80.5 & 76.4 & & 19.6 & 23.6 & & $1.15-1.27$ \\
\hline \multicolumn{8}{|l|}{ MI } \\
\hline Count & 555,650 & 5,536 & 561,186 & 25,150 & 272 & 25,422 & 1.08 \\
\hline$\%^{a}$ & 95.7 & 95.3 & & 4.3 & 4.7 & & $0.96-1.22$ \\
\hline
\end{tabular}

Abbreviations: ALS = amyotrophic lateral sclerosis; $\mathrm{MI}=$ myocardial infarction; $\mathrm{RR}=$ risk ratio.

Note 0.5 was added to the case count for anorexia to enable estimation of the RR. Bold type face is used for RR significantly different from 1.

a Percent of either case or control count.

twin-based estimate ${ }^{3}(0.61 \%, 95 \%$ CI, $0.38-0.78 \%)$ but is in good agreement with later estimates (table 1).

The published estimate of the genetic correlation derived from ALS and schizophrenia GWAS data is 0.14 ( $95 \%$ CI, $0.07-0.21) .{ }^{14}$ Although psychosis has been reported in relatives of those with ALS in kindred segregating the C9orf72 hexanucleotide repeat expansion, ${ }^{2}$ increased rates of ALS in those with schizophrenia have not been reported, which would be expected if there was a shared genetic architecture between the disorders. Here, we found no evidence for increased rates of schizophrenia in those with ALS (RR 0.86, 95\% CI, 0.57-1.30). However, the life expectancy is significantly reduced for those with schizophrenia: reported from survival analysis using the Danish registry data to be 18.7 years and 16.3 years shorter for men and women, respectively. ${ }^{30}$ The observed increased rate of schizophrenia in first-degree relatives of those with ALS was also not significant $(1.17 ; 95 \% \mathrm{CI}, 0.96-1.42 ; p=0.10)$, but the $\mathrm{RR}$ expected from a genetic correlation of 0.14 is 1.32 , which is within the confidence limits of our estimate. Hence, our results provide some support that the genetic relationship between ALS and schizophrenia is genetic. A Swedish national registry study, which identified 3,648 ALS cases and 364,800 matched controls found higher rates of psychiatric disorders in children of those with ALS. ${ }^{31}$ The overlap between ALS and schizophrenia is unlikely to be attributed to C9orf72 mutations 
Table 5 Disease/disorder counts in first-degree relatives of ALS cases and controls, and RRs for ALS cases compared to ALS controls

\begin{tabular}{|c|c|c|c|c|c|c|c|}
\hline & \multicolumn{3}{|c|}{$\begin{array}{l}\text { No first-degree relatives with } \\
\text { the given disorder }\end{array}$} & \multicolumn{3}{|c|}{$\begin{array}{l}\text { One or more first-degree relatives with } \\
\text { the given disorder }\end{array}$} & \multirow[b]{2}{*}{ RR $95 \% \mathrm{Cl}$} \\
\hline & Control & Case & Total & Control & Case & Total & \\
\hline \multicolumn{8}{|l|}{ ALS } \\
\hline Count & 433,005 & 4,270 & 437,275 & 662 & 38 & 700 & 5.78 \\
\hline$\%^{a}$ & 99.8 & 99.1 & & 0.2 & 0.9 & & $4.17-8.00$ \\
\hline \multicolumn{8}{|c|}{ All mental disorders } \\
\hline Count & 321,560 & 3,169 & 324,729 & 110,622 & 1,121 & 111,743 & 1.02 \\
\hline$\%^{a}$ & 74.4 & 73.9 & & 25.6 & 26.1 & & $0.97-1.07$ \\
\hline \multicolumn{8}{|c|}{ Schizophrenia } \\
\hline Count & 423,146 & 4,185 & 427,331 & 9,036 & 105 & 9,141 & 1.17 \\
\hline$\%^{a}$ & 97.9 & 97.6 & & 2.1 & 2.4 & & $0.97-1.42$ \\
\hline \multicolumn{8}{|c|}{ Other psychotic disorders } \\
\hline Count & 422,172 & 4,188 & 426,360 & 10,010 & 102 & 10,112 & 1.03 \\
\hline$\%^{a}$ & 97.7 & 97.6 & & 2.3 & 2.4 & & $0.85-1.24$ \\
\hline \multicolumn{8}{|c|}{ Bipolar disorder } \\
\hline Count & 424,690 & 4,215 & 428,905 & 7,492 & 75 & 7,567 & 1.01 \\
\hline$\%^{a}$ & 98.3 & 98.3 & & 1.7 & 1.7 & & $0.80-1.26$ \\
\hline \multicolumn{8}{|c|}{ Other affective disorders } \\
\hline Count & 393,344 & 3,915 & 397,259 & 38,838 & 375 & 39,213 & 0.97 \\
\hline$\%^{a}$ & 91.0 & 91.3 & & 9.0 & 8.7 & & $0.88-1.07$ \\
\hline \multicolumn{8}{|c|}{ Anorexia } \\
\hline Count & 430,662 & 4,277 & 434,939 & 1,520 & 13 & 1,533 & 0.86 \\
\hline$\%^{a}$ & 99.6 & 99.7 & & 0.4 & 0.3 & & $0.50-1.49$ \\
\hline \multicolumn{8}{|c|}{ Heart disease } \\
\hline Count & 278,665 & 2,832 & 281,497 & 153,517 & 1,458 & 154,975 & 0.96 \\
\hline$\%^{a}$ & 64.5 & 66.0 & & 35.5 & 34.0 & & $0.92-1.00$ \\
\hline \multicolumn{8}{|l|}{ MI } \\
\hline Count & 398,155 & 3,984 & 402,139 & 34,027 & 306 & 34,333 & 0.91 \\
\hline$\%^{a}$ & 92.1 & 92.9 & & 7.9 & 7.1 & & $0.81-1.01$ \\
\hline
\end{tabular}

Abbreviations: $\mathrm{ALS}=$ amyotrophic lateral sclerosis; $\mathrm{MI}=$ myocardial infarction; $\mathrm{RR}=$ risk ratio.

Bold type face is used for RR significantly different from 1. Note: Only persons with recorded first-degree relatives are included. First-degree relatives accounting parents, full siblings, and children.

a Percent of either case or control count.

because the hexanucleotide repeat is reported to have a frequency less than $0.1 \%$ in those with schizophrenia. ${ }^{32}$

We found increased rates of recorded cardiovascular disease (CVD) before diagnosis of ALS (RR = $1.21 ; 95 \% \mathrm{CI}$, $1.15-1.27)$, as previously reported. ${ }^{16}$ This association, however, was not detected in the narrow definition of heart disease; MI. By contrast, we found no increase in the rate of CVD among relatives of those with ALS, despite high rates in firstdegree relatives of both the cases and controls $(\sim 35 \%)$. This may suggest broad lifestyle factors, rather than a genetic relationship, and explain the observed increased rates of CVD in those with ALS, ${ }^{16}$ which would be consistent with the genetic correlation estimates from GWAS data between ALS and CVD that were not different from zero. ${ }^{15}$ Alternatively, the high rate of CVD recorded before ALS diagnosis may reflect the 
increased medical surveillance in those in the early stages of disease.

The key strength of the Danish registry data is its completeness so that ascertainment biases are minimized compared with other designs. Nonetheless, there are limitations. First, because ALS is a late-onset disorder and given the timing of the establishment of the registry system, we could only trace parents for those born after $\sim 1950$. From the parents, we were able to trace the siblings, but only siblings born after 1950 . To counter this, our design of 100 controls per case provides robustness to our estimates and any potential biases apply to both cases and controls. Second, although $\sim 70 \%$ of ALS cases had records of first-degree relatives in the registry system, the majority of such relatives were children, who were mostly below the expected age of ALS onset (median age diagnosis in these data of 67.1 years). The information for estimation of heritability was therefore mostly generated from $\sim 15 \%$ of the ALS cases that could be linked to both parents and hence also to siblings, which is still a sizeable data set (table 1). Third, in these registry data, we were unable to identify individuals and their family members carrying ALS causal mutations and inclusion of these individuals could inflate the estimate of heritability, which methodologically assumes a polygenic architecture. We did not attempt to access frontotemporal dementia diagnoses (relevant because it co-occurs in families carrying the C9orf 72 hexanucleotide repeat ${ }^{33}$ ) because these diagnoses have not been validated in registry data. ${ }^{34}$ To address these limitations, we conducted sensitivity analyses in which we excluded from the analyses a proportion of concordant relative pairs, the proportion chosen as a likely upper limit that could be attributed to first-degree relative pairs with causal mutations. The resulting relative risk $(\mathrm{RR}=4.57 ; 95 \% \mathrm{CI}, 3.17-6.58)$ and heritability $(\mathrm{RR}=0.36$; 95\% CI, 0.27-0.47) provide lower bounds of these estimates. Last, higher relative risks associated with maternal transmission have recently been reported in a prospective ALS study in Ireland, ${ }^{7}$ although results were not significant when families carrying the C9orf72 hexanucleotide repeat expansion were excluded. Here, we have not considered sex-specific risks because the number of concordant affected pairs is too few to generate meaningful results.

Our heritability estimate of 0.43 withstands sensitivity analyses and supports a genetic contribution to the disease. If anything, our estimate might be upwardly biased, yet the estimate is lower than the twin estimate of heritability of ALS that has been most often cited. The weight of evidence is now such that a lower estimate must be seen as more plausible (table 1 ), we suggest $\sim 0.40$. We find evidence for previous risk of psychiatric disorders and CVD in individuals with ALS, plus tentative evidence that this relationship has a genetic contribution for schizophrenia and other psychiatric disorders but not for CVD.

\section{Acknowledgment}

N.R.W. and F.C.G. acknowledge funding from the Australian National Health and Medical Research Council (1078901, 1113400, 1087889). B.B.T., P.B.M., and E.A. acknowledge financial support from The Stanley Medical Research Institute and The Lundbeck Foundation Initiative for Integrative Psychiatric Research, iPSYCH (grant no. R102-A9118 and R155-2014-1724).

\section{Study funding}

The Australian National Health and Medical Research Council (1078901, 1113400, 1087889) to N.R.W. and F.G. The Stanley Medical Research Institute and The Lundbeck Foundation Initiative for Integrative Psychiatric Research, iPSYCH (grant no. R102-A9118 and R155-2014-1724) to B.B.T., P.B.M., and E.A.

\section{Disclosure}

B.B. Trabjerg, F.C. Garton, W. van Rheenen, F. Fang, R.D. Henderson, P.B. Mortensen, E. Agerbo, and N.R. Wray report no disclosures. Go to Neurology.org/NG for full disclosures.

\section{Publication history}

Received by Neurology: Genetics September 10, 2019. Accepted in final form January 13, 2020.

\begin{tabular}{|c|c|c|c|}
\hline Name & Location & Role & Contribution \\
\hline $\begin{array}{l}\text { Betina B. } \\
\text { Trabjerg, } \\
\text { MSc }\end{array}$ & $\begin{array}{l}\text { Aarhus } \\
\text { University, } \\
\text { Denmark }\end{array}$ & Author & $\begin{array}{l}\text { Analysis of the Danish } \\
\text { registry data }\end{array}$ \\
\hline $\begin{array}{l}\text { Fleur C. } \\
\text { Garton, PhD }\end{array}$ & $\begin{array}{l}\text { The University of } \\
\text { Queensland, } \\
\text { Brisbane, } \\
\text { Australia }\end{array}$ & Author & $\begin{array}{l}\text { Analysis applied to the } \\
\text { summary statistics } \\
\text { derived from the Danish } \\
\text { registry data. Manuscript } \\
\text { first draft. }\end{array}$ \\
\hline $\begin{array}{l}\text { Wouter van } \\
\text { Rheenen, } \\
\text { MD, PhD }\end{array}$ & $\begin{array}{l}\text { University } \\
\text { medical Center } \\
\text { Utrecht, The } \\
\text { Netherlands }\end{array}$ & Author & $\begin{array}{l}\text { Study design and ALS } \\
\text { interpretation }\end{array}$ \\
\hline $\begin{array}{l}\text { Fang Fang, } \\
\text { MD, PhD }\end{array}$ & $\begin{array}{l}\text { Karolinska } \\
\text { Institutet, } \\
\text { Stockholm, } \\
\text { Sweden }\end{array}$ & Author & $\begin{array}{l}\text { Study design and } \\
\text { interpretation }\end{array}$ \\
\hline $\begin{array}{l}\text { Robert D. } \\
\text { Henderson, } \\
\text { MBBS, PhD }\end{array}$ & $\begin{array}{l}\text { The University of } \\
\text { Queensland, } \\
\text { Brisbane, } \\
\text { Australia }\end{array}$ & Author & $\begin{array}{l}\text { Study design and ALS } \\
\text { interpretation }\end{array}$ \\
\hline $\begin{array}{l}\text { Preben Bo } \\
\text { Mortensen, } \\
\text { DrMedSc }\end{array}$ & $\begin{array}{l}\text { Aarhus } \\
\text { University, } \\
\text { Denmark }\end{array}$ & Author & $\begin{array}{l}\text { Supervision of the } \\
\text { analysis of Danish registry } \\
\text { data; study design }\end{array}$ \\
\hline $\begin{array}{l}\text { Esben } \\
\text { Agerbo, } \\
\text { DrMedSc }\end{array}$ & $\begin{array}{l}\text { Aarhus } \\
\text { University, } \\
\text { Denmark }\end{array}$ & Author & $\begin{array}{l}\text { Supervision of the } \\
\text { analysis of Danish registry } \\
\text { data; study design }\end{array}$ \\
\hline $\begin{array}{l}\text { Naomi R. } \\
\text { Wray, PhD }\end{array}$ & $\begin{array}{l}\text { The University of } \\
\text { Queensland, } \\
\text { Brisbane, } \\
\text { Australia }\end{array}$ & Author & $\begin{array}{l}\text { Study design. Analysis } \\
\text { applied to the summary } \\
\text { statistics derived from the } \\
\text { Danish registry data. } \\
\text { Manuscript first draft. }\end{array}$ \\
\hline
\end{tabular}

\section{References}

1. Taylor JP, Brown RH Jr, Cleveland DW. Decoding ALS: from genes to mechanism. Nature 2016;539:197-206. 
2. Byrne $\mathrm{S}$, Walsh $\mathrm{C}$, Lynch $\mathrm{C}$, et al. Rate of familial amyotrophic lateral sclerosis: a systematic review and meta-analysis. J Neurol Neurosurg Psychiatry 2011;82: 623-627.

3. Al-Chalabi A, Fang F, Hanby MF, et al. An estimate of amyotrophic lateral sclerosis heritability using twin data. J Neurol Neurosurg Psychiatry 2010;81:1324-1326.

4. Fang F, Kamel F, Lichtenstein P, et al. Familial aggregation of amyotrophic lateral sclerosis. Ann Neurol 2009;66:94-99.

5. Wingo TS, Cutler DJ, Yarab N, Kelly CM, Glass JD. The heritability of amyotrophic lateral sclerosis in a clinically ascertained United States research registry. PLoS One 2011;6:e27985.

6. Hanby MF, Scott KM, Scotton W, et al. The risk to relatives of patients with sporadic amyotrophic lateral sclerosis. Brain 2011;134:3454-3457.

7. Ryan M, Heverin M, McLaughlin RL, Hardiman O. Lifetime risk and heritability of amyotrophic lateral sclerosis. JAMA Neurol 2019;76:1367-1374.

8. Alonso A, Logroscino G, Jick SS, Hernan MA. Incidence and lifetime risk of motor neuron disease in the United Kingdom: a population-based study. Eur J Neurol 2009;16:745-751.

9. Kiernan MC, Vucic S, Cheah BC, et al. Amyotrophic lateral sclerosis. Lancet 2011; 377:942-955.

10. Yang J, Zeng J, Goddard ME, Wray NR, Visscher PM. Concepts, estimation and interpretation of SNP-based heritability. Nat Genet 2017;49:1304.

11. van Rheenen W, Shatunov A, Dekker AM, et al. Genome-wide association analyses identify new risk variants and the genetic architecture of amyotrophic lateral sclerosis. Nat Genet 2016;48:1043-1048.

12. Lee SH, Yang J, Goddard ME, Visscher PM, Wray NR. Estimation of pleiotropy between complex diseases using single-nucleotide polymorphism-derived genomic relationships and restricted maximum likelihood. Bioinformatics 2012;28:2540-2542.

13. Bulik-Sullivan B, Finucane HK, Anttila V, et al. An atlas of genetic correlations across human diseases and traits. Nat Genet 2015;47:1236-1241.

14. McLaughlin RL, Schijven D, van Rheenen W, et al. Genetic correlation between amyotrophic lateral sclerosis and schizophrenia. Nat Commun 2017;8:14774.

15. Bandres-Ciga S, Noyce AJ, Hemani G, et al. Shared polygenic risk and causal inferences in amyotrophic lateral sclerosis. Ann Neurol 2019;85:470-481.

16. Kioumourtzoglou MA, Seals RM, Gredal O, Mittleman MA, Hansen J, Weisskopf MG. Cardiovascular disease and diagnosis of amyotrophic lateral sclerosis: a population based study. Amyotroph Lateral Scler Frontotemporal Degeneration 2016;17: 548-554.

17. Pedersen CB. The Danish Civil Registration system. Scand J Public Health 2011;39: $22-25$.

18. Lynge E, Sandegaard JL, Rebolj M. The Danish national patient register. Scand J Public Health 2011;39:30-33.

19. Kioumourtzoglou MA, Seals RM, Himmerslev L, Gredal O, Hansen J, Weisskopf MG Comparison of diagnoses of amyotrophic lateral sclerosis by use of death certificates and hospital discharge data in the Danish population. Amyotroph Lateral Scler Frontotemporal Degener 2015;16:224-229.
20. Laursen TM, Munk-Olsen T, Agerbo E, Gasse C, Mortensen PB. Somatic hospital contacts, invasive cardiac procedures, and mortality from heart disease in patients with severe mental disorder. Arch Gen Psychiatry 2009;66:713-720.

21. Seals RM, Hansen J, Gredal O, Weisskopf MG. Age-period-cohort analysis of trends in amyotrophic lateral sclerosis in Denmark, 1970-2009. Am J Epidemiol 2013;178: 1265-1271.

22. Seals RM, Kioumourtzoglou MA, Hansen J, Gredal O, Weisskopf MG. Amyotrophic lateral sclerosis and the Military: a population-based study in the Danish Registries. Epidemiology 2016;27:188-193.

23. Mors O, Perto GP, Mortensen PB. The Danish psychiatric Central research register. Scand J Public Health 2011;39:54-57.

24. Pedersen CB, Mors O, Bertelsen A, et al. A Comprehensive nationwide study of the incidence rate and lifetime risk for treated mental disorders. JAMA Psychiatry 2014; $71: 573-581$.

25. Yang J, Visscher PM, Wray NR. Sporadic cases are the norm for complex disease. Eur J Hum Genet 2010;18:1039-1043.

26. Reich T, Morris CA, James JW. Use of multiple thresholds in determining mode of transmission of semi-continuous traits. Ann Hum Genet 1972;36:163-184.

27. Falconer DS. Inheritance of liability to certain diseases estimated from incidence among relatives. Ann Hum Genet 1965;29:51-76.

28. Wray NR, Gottesman II. Using summary data from the Danish national registers to estimate heritabilities for schizophrenia, bipolar disorder, and major depressive disorder. Front Genet 2012;3:118.

29. Majounie E, Renton AE, Mok K, et al. Frequency of the C9orf72 hexanucleotide repeat expansion in patients with amyotrophic lateral sclerosis and frontotemporal dementia: a cross-sectional study. Lancet Neurol 2012;11:323-330.

30. Laursen TM. Life expectancy among persons with schizophrenia or bipolar affective disorder. Schizophr Res 2011;131:101-104.

31. Longinetti E, Mariosa D, Larsson $\mathrm{H}$, et al. Neurodegenerative and psychiatric diseases among families with amyotrophic lateral sclerosis. Neurology 2017;89: 578-585.

32. Ducharme S, Bajestan S, Dickerson BC, Voon V. Psychiatric Presentations of C9orf72 mutation: what are the diagnostic implications for Clinicians? J Neuropsychiatry Clin Neurosci 2017;29:195-205.

33. Rohrer JD, Isaacs AM, Mizielinska S, et al. C9orf72 expansions in frontotemporal dementia and amyotrophic lateral sclerosis. Lancet Neurol 2015;14: 291-301.

34. Phung TK, Andersen BB, Hogh P, Kessing LV, Mortensen PB, Waldemar G. Validity of dementia diagnoses in the Danish hospital registers. Dement Geriatr Cogn Disord 2007;24:220-228.

35. Graham AJ, Macdonald AM, Hawkes $\mathrm{CH}$. British motor neuron disease twin study. J Neurol Neurosurg Psychiatry 1997;62:562-569.

36. Hanby MF, Scott KM, Scotton W, et al. The risk to relatives of patients with sporadic amyotrophic lateral sclerosis. Brain 2011;134:3454-3457. 


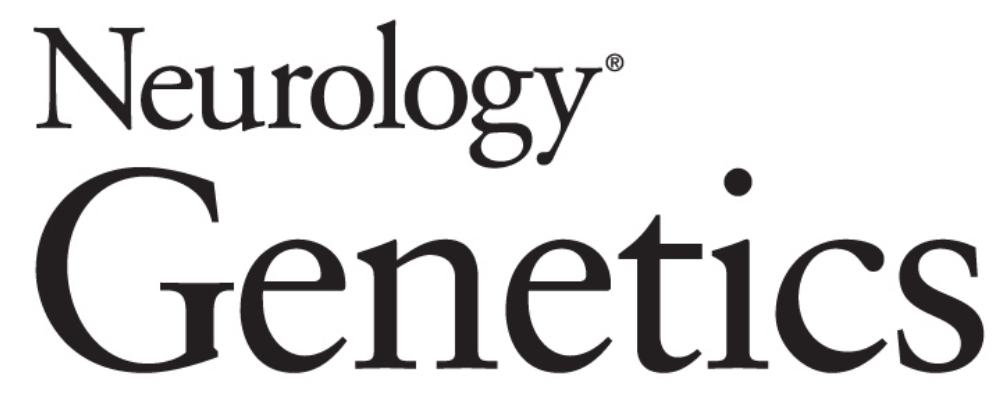
ALS in Danish Registries: Heritability and links to psychiatric and cardiovascular disorders
Betina B. Trabjerg, Fleur C. Garton, Wouter van Rheenen, et al.
Neurol Genet 2020;6;
DOI 10.1212/NXG.0000000000000398

This information is current as of February 20, 2020

Neurol Genet is an official journal of the American Academy of Neurology. Published since April 2015, it is an open-access, online-only, continuous publication journal. Copyright Copyright $\odot 2020$ The Author(s). Published by Wolters Kluwer Health, Inc. on behalf of the American Academy of Neurology.. All rights reserved. Online ISSN: 2376-7839.

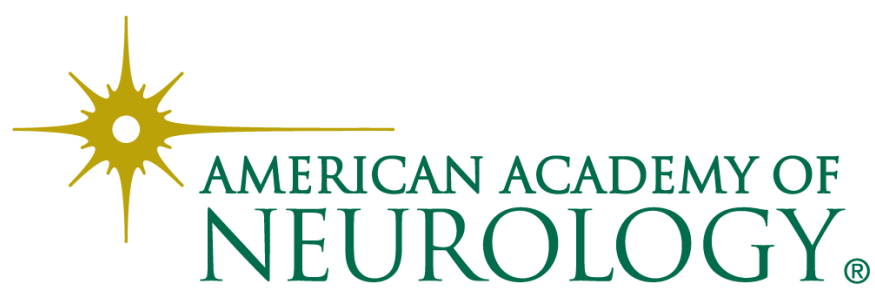




\section{Updated Information \& Services}

References

Citations

Subspecialty Collections

\section{Permissions \& Licensing}

Reprints including high resolution figures, can be found at: http://ng.neurology.org/content/6/2/e398.full.html

This article cites 36 articles, 3 of which you can access for free at: http://ng.neurology.org/content/6/2/e398.full.html\#\#ref-list-1

This article has been cited by 8 HighWire-hosted articles: http://ng.neurology.org/content/6/2/e398.full.html\#\#otherarticles

This article, along with others on similar topics, appears in the following collection(s):

\section{All epidemiology}

http://ng.neurology.org//cgi/collection/all_epidemiology

All Genetics

http://ng.neurology.org//cgi/collection/all_genetics

All Psychiatric disorders

http://ng.neurology.org//cgi/collection/all_psychiatric_disorders

Amyotrophic lateral sclerosis

http://ng.neurology.org//cgi/collection/amyotrophic_lateral_sclerosis_

Information about reproducing this article in parts (figures,tables) or in its entirety can be found online at:

http://ng.neurology.org/misc/about.xhtml\#permissions

Information about ordering reprints can be found online:

http://ng.neurology.org/misc/addir.xhtml\#reprintsus

Neurol Genet is an official journal of the American Academy of Neurology. Published since April 2015, it is an open-access, online-only, continuous publication journal. Copyright Copyright $\odot 2020$ The Author(s). Published by Wolters Kluwer Health, Inc. on behalf of the American Academy of Neurology.. All rights reserved. Online ISSN: 2376-7839.

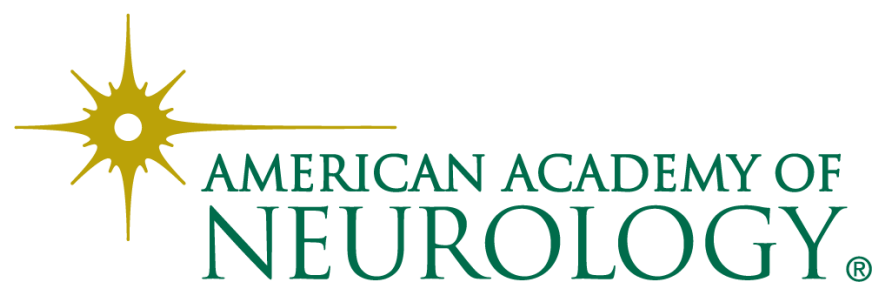

